ORNL/TM-2020/1673

Light Water Reactor Sustainability Program

Conduct weld campaign (FY-21-1) on irradiated materials provided by the Canadian Nuclear Laboratory (CNL), including baseline post-weld evaluation and testing

M2LW-210R0406013

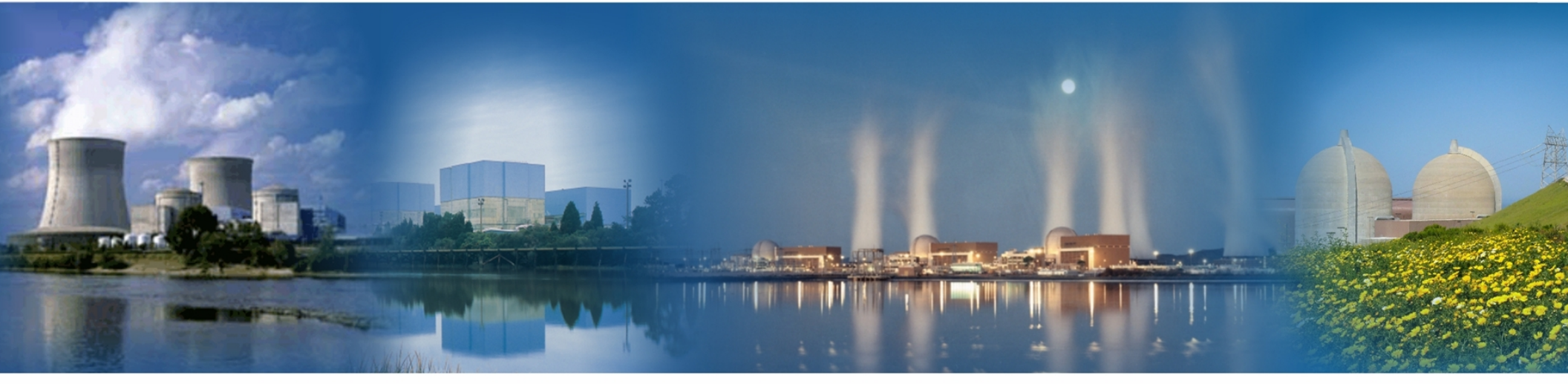

August 2021

U.S. Department of Energy Office of Nuclear Energy 


DISCLAIMER 1
This manuscript has been authored by UT-Battelle, LLC under
Contract No. DE-AC05-00OR22725 with the U.S. Department of Energy.
The United States Government retains and the publisher, by accepting the
article for publication, acknowledges that the United States Government
retains a non-exclusive, paid-up, irrevocable, worldwide license to publish
or reproduce the published form of this manuscript, or allow others to do
so, for United States Government purposes. The Department of Energy will
provide public access to these results of federally sponsored research in
accordance with the DOE Public Access Plan
(http://energy.gov/downloads/doe-public-access-plan).

DISCLAIMER 2
This information was prepared as an account of work sponsored by an
agency of the U.S. Government. Neither the U.S. Government nor any
agency thereof, nor any of their employees, makes any warranty, expressed
or implied, or assumes any legal liability or responsibility for the accuracy,
completeness, or usefulness, of any information, apparatus, product, or
process disclosed, or represents that its use would not infringe privately
owned rights. References herein to any specific commercial product,
process, or service by trade name, trademark, manufacturer, or otherwise,
does not necessarily constitute or imply its endorsement, recommendation,
or favoring by the U.S. Government or any agency thereof. The views and
opinions of authors expressed herein do not necessarily state or reflect
those of the U.S. Government or any agency thereof.




\section{CONDUCT WELD CAMPAIGN (FY-21-1) ON IRRADIATED MATERIALS PROVIDED BY THE CANADIAN NUCLEAR LABORATORY (CNL), INCLUDING BASELINE POST-WELD EVALUATION AND TESTING}

$$
\text { M2LW-21OR0406013 }
$$

Jian Chen, Zhili Feng, Roger Miller and Scott White

Oak Ridge National Laboratory

Wenjing Li and Lori Walters

Canadian Nuclear Laboratories

Jonathan Tatman and Greg Frederick

Electric Power Research Institute

August 2021

Prepared by

OAK RIDGE NATIONAL LABORATORY

Oak Ridge, TN 37831-6283

managed by

UT-BATTELLE, LLC

for the

US DEPARTMENT OF ENERGY

under contract DE-AC05-00OR22725 


\section{CONTENTS}

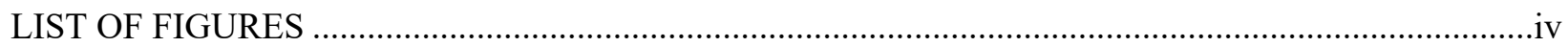

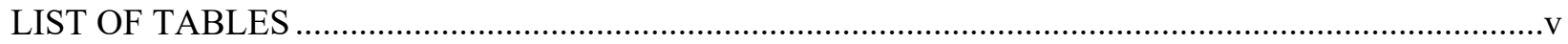

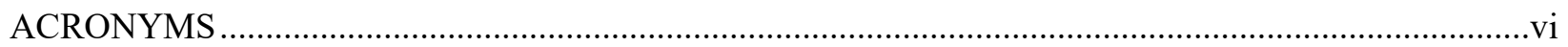

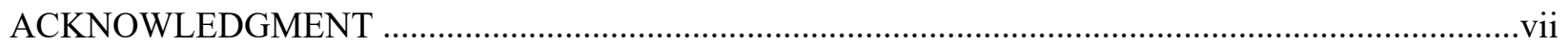

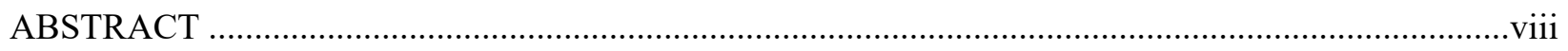

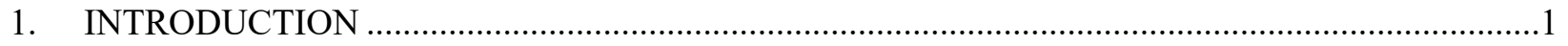

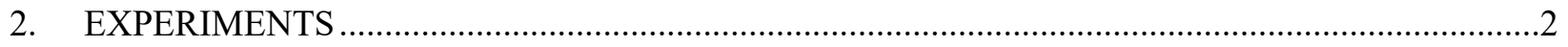

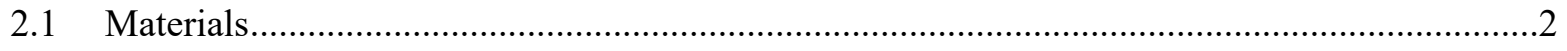

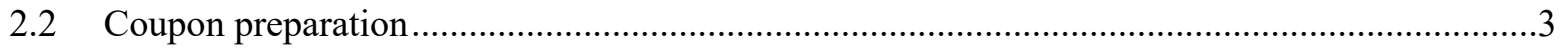

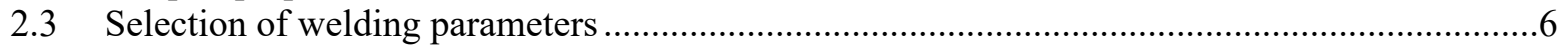

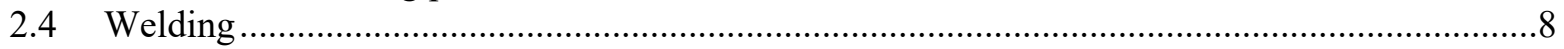

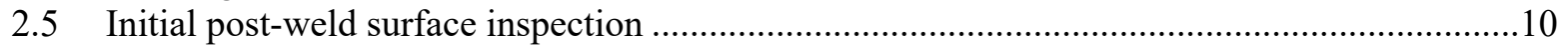

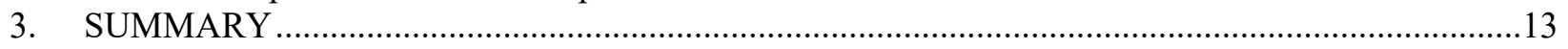

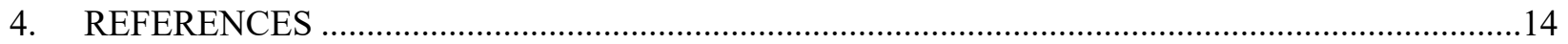




\section{LIST OF FIGURES}

Figure 1 A NRU Flux Detector cup and its geometry.

Figure 2 (a) A FD cup with schematic cutting diagram (b) the fixture for cutting welding coupons and the dummy coupons cut from an unirradiated FD cup...

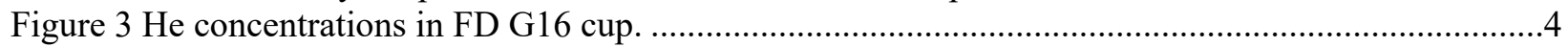

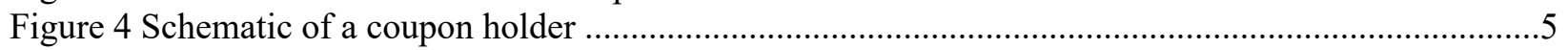

Figure 5 Irradiated SS304 coupons installed in three holders ...........................................................6

Figure $6 \mathrm{~A}$ threshold of effective welding heat input (dashed line) as a function of helium concentration below which no HeIC formed (green symbols). Above the threshold, welds had a high tendency to crack (red symbols). Effective heat inputs used in welding of ORNL's boron dopped SS304 coupons and CNL's SS304 coupons are also indicated in the figure.

Figure 7 Schematics of weld passes and photos of the welded CNL's irradiated SS304 coupons in (a) Holder 1, (b) Holder 2 and (c) Holder 3. P1 to P6 denotes the sequence of weld passes.

Figure 8 Initial surface inspection of the welded SS304 coupons. P1 to P6 denotes the sequence of weld passes. 


\section{LIST OF TABLES}

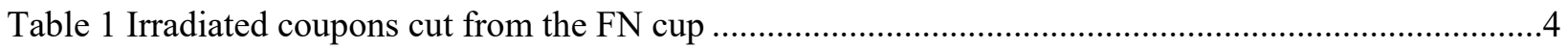

Table 2 Three coupon holders containing weld coupons with varying He concentrations ........................6

Table 3 Welding parameters in previous trials on CNL's unirradiated SS304 ........................................

Table 4 Welding parameters used in the current trial on CNL's irradiated SS304 .................................. 


\section{ACRONYMS}

ABSI-LW auxiliary beam stress improved laser welding

appm atomic parts per million

CNL Canadian Nuclear Laboratories

DIC digital image correlation

DOE Department of Energy

EDM electrical discharge machining

EPRI Electric Power Research Institute

HAZ heat-affected zone

HeIC helium induced cracking

LTO Long-Term Operation

LW laser weld

LWRS Light Water Reactor Sustainability

NE Office of Nuclear Energy

ORNL Oak Ridge National Laboratory

SEM/EDS scanning electron microscopy/energy-dispersive X-ray spectroscopy

THDS thermal helium desorption spectroscopy

VAR vacuum arc remelting

VTI Vacuum Technology Incorporated

wppm weight parts per million 


\section{ACKNOWLEDGMENT}

This research was sponsored by the US Department of Energy (DOE), Office of Nuclear Energy (NE), under contract No. DE-AC05-00OR22725 with Oak Ridge National Laboratory (ORNL), managed and operated by UT-Battelle, LLC.

The authors gratefully acknowledge the program support of Thomas. M. Rosseel, Materials Research Pathway Lead of the Light Water Reactor Sustainability Program at ORNL; engineering support of Kurt Smith and Bob Sitterson; hot cell facilities and operations contributions of Mark Delph, Clay Morris, Tony Davis, Kevin Delabar, Rick Bowman, Scott Thurman, and Allen Smith. 


\begin{abstract}
A collaborative research on developing advanced welding technologies for irradiated stainless steel 304 materials between CNL and ORNL has been established to support both U.S. and Canadian interests in evaluation of weld repair techniques on irradiated materials to support continuous operation of commercial nuclear power. The work utilizes unique material from the National Research Universal (NRU) reactor and the specialized welding hot cell facility at ORNL. The objective is to explore suitable welding technique and parameters and to determine the helium concentration limitation in terms of irradiated stainless-steel weldability. An additional objective is to develop the knowledge and understanding of cracking mechanisms induced by high concentration of helium in the process of weld repair of the irradiated structural alloys. This report summarizes the experimental welding evaluation on irradiated material from the NRU reactor containing helium concentrations ranging from 12 to 45 atomic parts per million (appm).

This report also fulfills the FY 2021 LWRS milestone M2LW-21OR0406013, "Conduct Weld Campaign (FY21-1) on irradiated materials provided by the Canadian Nuclear Laboratory (CNL), including baseline post-weld evaluation and testing."
\end{abstract}




\section{INTRODUCTION}

Today, welding is widely used for repair, maintenance, and the upgrade of nuclear reactor components. Welding technology is critical to extend the service life of nuclear power plants (NPPs) beyond 60 years and must be further developed to meet new challenges associated with the aging of the plants, such as control and mitigation of the detrimental effects of weld residual stresses and repair of highly irradiated materials. To meet this goal, a fundamental understanding of the welding strength and weakness is necessary for the development of new and improved welding technologies.

Welding repair of irradiated nuclear reactor materials (such as austenitic stainless steels used for the reactor internals) is very challenging because the existence of helium in the steel, even at very low levels (i.e., parts per million), can cause cracking during repair welding. Helium is a product of the boron and nickel transmutation process under intense neutron irradiation. Under the influence of high temperatures and high tensile stresses during welding, rapid formation and growth of helium bubbles can occur at grain boundaries, resulting in intergranular cracking in the heat-affected zone (HAZ) - the so-called heliuminduced cracking (HeIC) (Kanne Jr. 1988). Over the past decades, a basic understanding has been established for the detrimental effects of weld stresses on HeIC (Feng and Wilkowski 2002) (Feng, Wolfe, et al. 2009). However, practical methods for weld repair of irradiated materials are still evolving. Industry's experience has been that today's arc-welding-based and laser-welding-based repair technologies are limited to situations where the helium in the irradiated materials is less than 1 appm. No welding restrictions are required for helium levels below $0.1 \mathrm{appm}$ helium. Restrictions on welding parameters such as welding heat input level are necessary when the helium levels are above $0.1 \mathrm{appm}$. Reactor internals with helium levels above 5-10 appm are generally considered not weldable (or weld repairable) using today's welding practices common to the industry (EPRI 2015) (JNES 2004).

As the service life of nuclear reactors in the United States are extended, the amount of helium in the structural materials in certain highly irradiated areas will continue to increase, reaching levels much higher than 10 appm. Therefore, innovations in repair welding technology are essential to addressing this critical industry need.

A joint effort between the US Department of Energy Office of Nuclear Energy (DOE NE) Light Water Reactor Sustainability (LWRS) Program and the Electric Power Research Institute (EPRI) Long-Term Operations (LTO) Program has recently demonstrated the success in welding of irradiated stainless steels (SS304 and SS316) using advanced laser welding. The irradiated stainless steels were produced by introduction of natural occurring boron in steel alloys and irradiation at ORNL's High Flux Isotope Reactor to mimic various levels of helium in materials exposed to up to 70 years of reactor operation.

In this collaborative research collaboration between ORNL and Canadian Nuclear Laboratories (CNL), the work utilizes the materials from the National Research Universal (NRU) reactor. The helium level in these reactor materials can reach as high as $900 \mathrm{appm}$. The objective is to utilize ORNL's welding facilities and laser welding techniques to explore the optimal welding conditions and to determine the He limitation in terms of weldability for irradiated stainless steel. The additional objective is to develop the knowledge and understanding of cracking mechanisms induced by high concentration of helium in the process of weld repair of the irradiated structural alloys. This report summarizes the collaborative research plan and work conducted on the design of the sample and clamping fixture, trial welding of unirradiated samples, and experimental laser welding of irradiated material from the NRU reactor. Welding experiments were conducted on nine irradiated samples with helium levels ranging from 10 to 45 appm. 


\section{EXPERIMENTS}

\subsection{Materials}

After the NRU reactor was permanently shut down in March 2018, a wide variety of in- and out-of-core materials and components from the reactor including irradiated SS304 bottom header cups became available for post-service examination and research. These cups were used to connect the bottom end of a fuel rod, control rod (CR), fast neutron (FN), or flux detector (FD) rod to the bottom header of the NRU vessel, and were threaded into the bottom header and are removable. Because they were exposed to relatively low flux in the core but for long durations, the thermal fluence was significantly high. The preliminary calculations indicate that they could contain He in a range of 10 to 900 appm produced from the transmutation of natural ${ }^{58} \mathrm{Ni}$, depending on the location and the length of time the cups were installed in the NRU reactor. So, those cup components provide great opportunities to evaluate the advanced weld techniques and He limits in terms of the weldability for irradiated stainless steel structural materials.

One of the FN cups was harvested from the reactor site G16 from NRU in May 2018 for weldability studies of irradiated SS 304. The extracted cup was vertically installed in the reactor and was irradiated at $35{ }^{\circ} \mathrm{C}$ for 45 years in the reactor prior to removal. Due to the elevation variation along with length of the cup, the exposure to the neutron flux/fluence increases from the bottom (thread section) to the top (conical section), as shown in Figure 1. The He content at the top of the conical section and the bottom of the tubular section were measured using Hot Vacuum Extraction Mass Spectrometry (HVEMS) at Canadian Nuclear Laboratories. The measured helium (He) concentration is a maximum of 306 appm at the top of the conical section, and a minimum of $12 \mathrm{appm}$ at the bottom of the tubular section. The threaded part of the cup had been removed during the campaign of the helium measurements because this section was exposed to levels of neutron irradiation too low to be of interest. A $20 \mathrm{~mm}$ wide section along the conical and tubular sections were removed from the cup during sectioning of the He samples. The rest of the conical and tubular sections will be used for welding research.
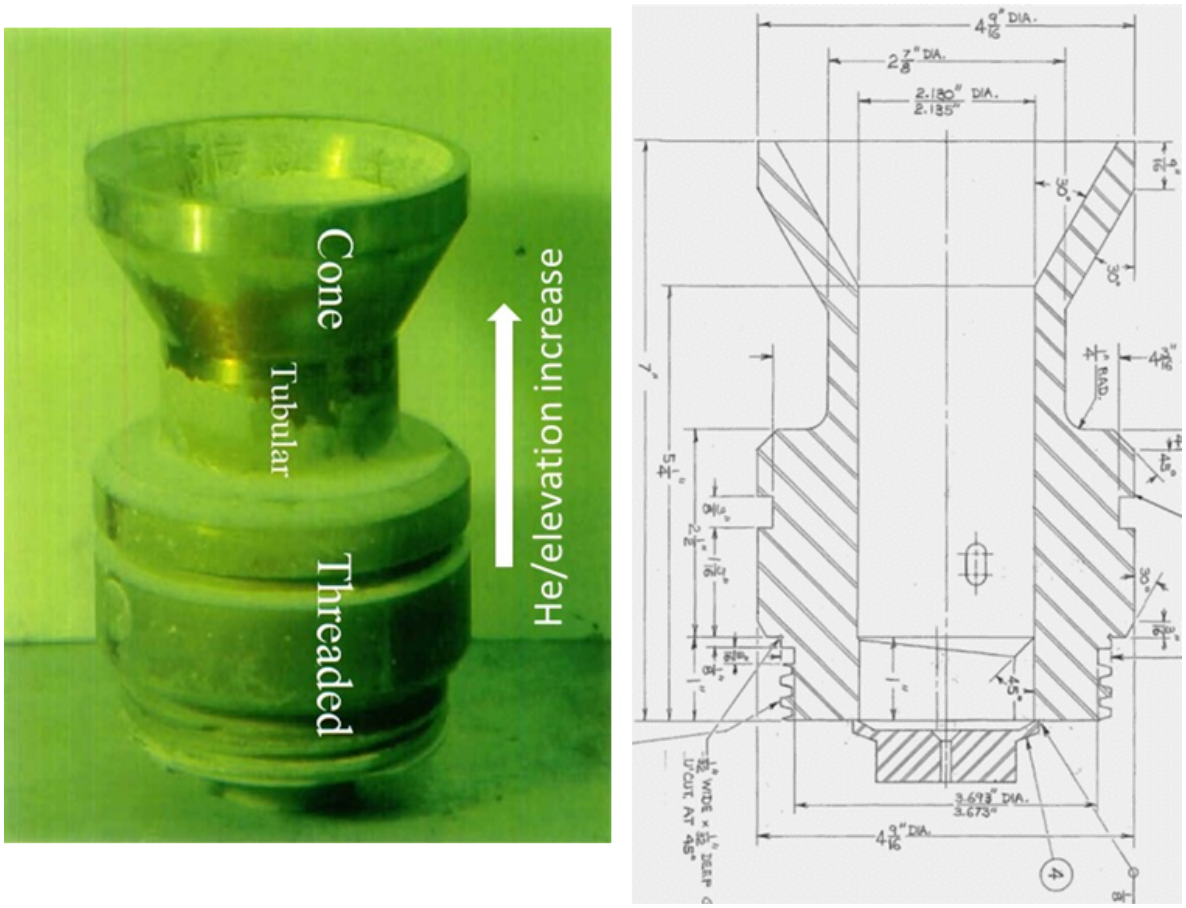

Figure 1 A NRU Flux Detector cup and its geometry. 


\subsection{Coupon preparation}

The CNL team has developed a cutting process to prepare weld coupons in which the cup was firstly cut into four pieces approximately 90 degrees apart (solid red lines), then, one of the quarters was further cut into welding coupons transverse to the longitudinal direction of the tubular and conical sections (dashed lines), as shown in Figure 2(a). This resulted in multiple flat ring segments (coupons) as shown in Figure 2(b)

(a)

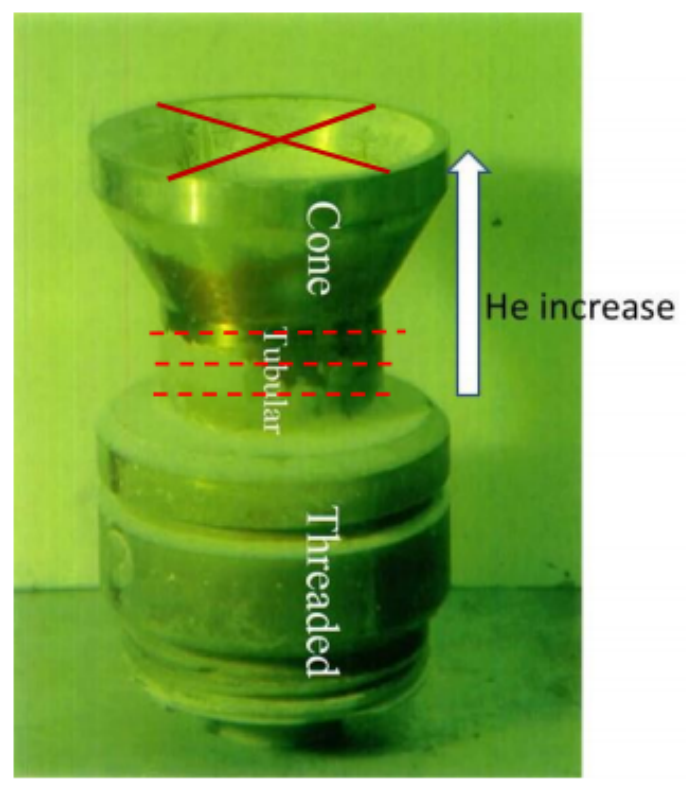

(b)

T3-T6 Tubular pieces, approx $3 \mathrm{~mm}$.

$\mathrm{C} 1, \mathrm{C2}$ - Conical pieces tapering as 8-9 samples for Final product

they aproach tubular section.

12-13 pieces for final product
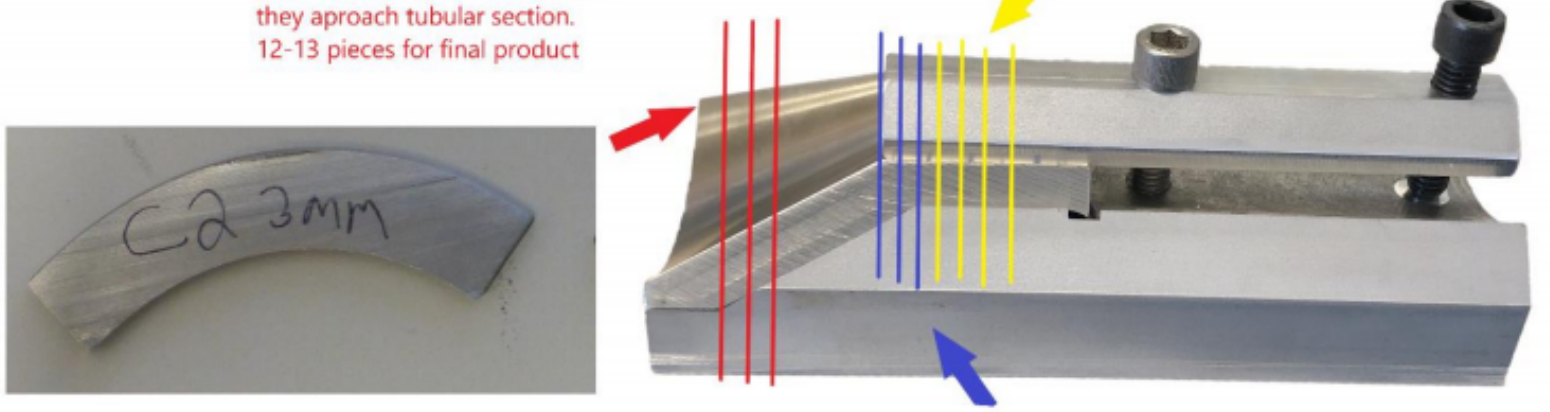

T1-T2, transistion pieces with a tubular inside profile and conical out side profile aprox. $3 \mathrm{~mm}$

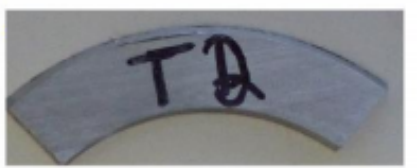

Figure 2 (a) A FD cup with schematic cutting diagram (b) the fixture for cutting welding coupons and the dummy coupons cut from an unirradiated FD cup. 
Coupon cutting and He measurement activities were conducted at CNL. Figure 3 shows the measured He concenrtation as a function of distance to the top of the cone. Nine coupons were cut out of the tube section, which had the highest He content up to approximately $45 \mathrm{appm}$. Table 1 lists the dimension, weight, and He concentration of each coupon. The He content on both surfaces of each coupon was estimated based on the fit curve of the measured He in Figure 3.

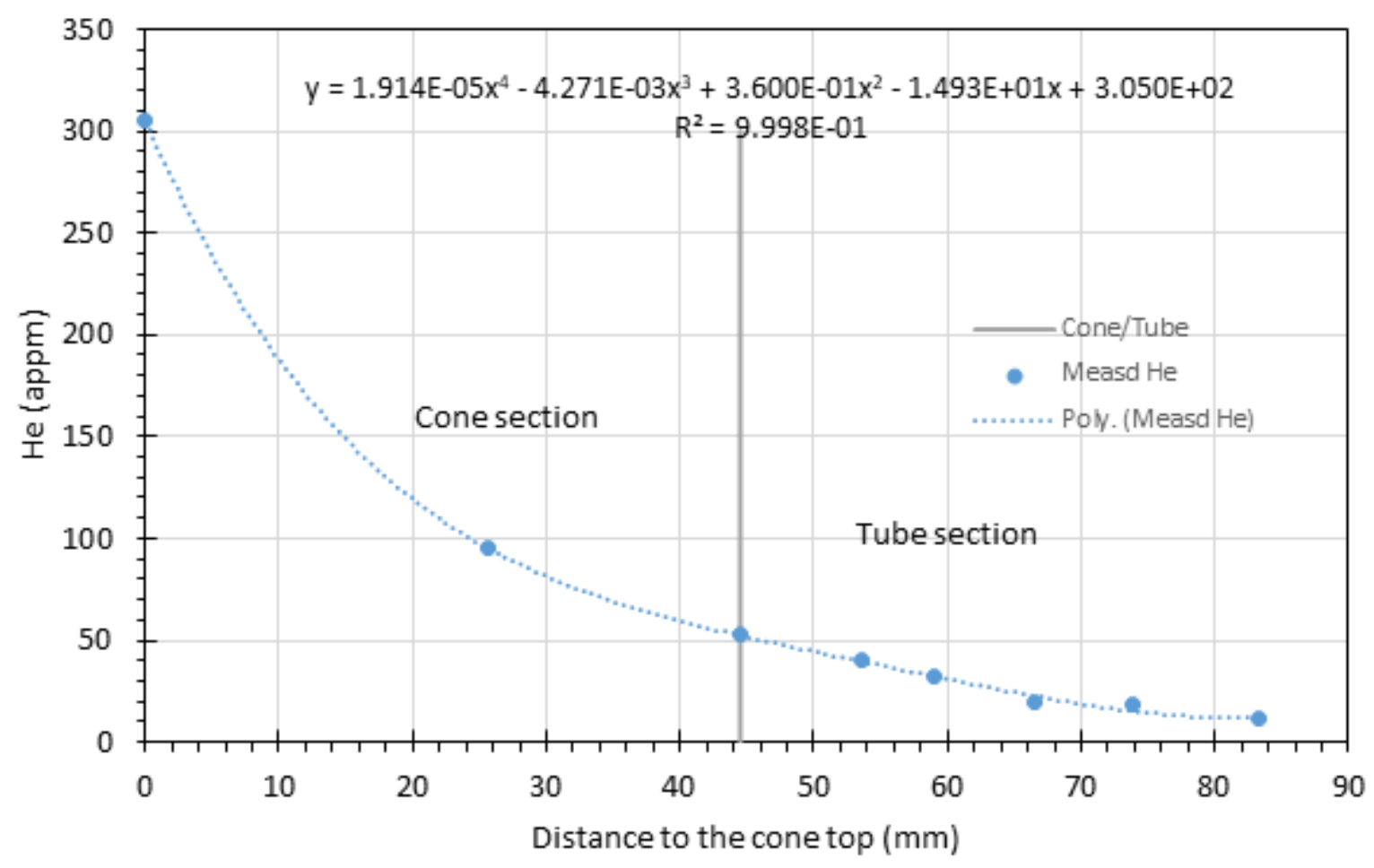

Figure 3 He concentrations in FD G16 cup.

Table 1 Irradiated coupons cut from the FN cup

\begin{tabular}{|c|c|c|c|c|c|c|c|c|}
\hline \multirow[t]{2}{*}{ Sample ID } & \multirow{2}{*}{$\begin{array}{c}\begin{array}{c}\text { Measured } \\
\text { Thickness \#1 } \\
(\mathrm{mm})\end{array} \\
\text { min }\end{array}$} & \multirow{2}{*}{$\begin{array}{c}\text { Measured } \\
\text { Thickness \#2 } \\
(\mathrm{mm}) \\
\max \end{array}$} & \multirow[t]{2}{*}{$\begin{array}{l}\text { Average } \\
\text { Thickness } \\
(\mathrm{mm})\end{array}$} & \multirow[t]{2}{*}{$\begin{array}{l}\text { Weight of } \\
\text { Sample }(\mathrm{g})\end{array}$} & \multicolumn{2}{|c|}{$\begin{array}{l}\text { Measured distance from } \\
\text { the top of cone (average of } \\
\text { sample) } \\
(\mathrm{mm})\end{array}$} & \multicolumn{2}{|c|}{ Fitted He content } \\
\hline & & & & & $\begin{array}{l}\text { Face } 1 \text { - to } \\
\text { tube end }\end{array}$ & $\begin{array}{l}\text { Face } 2 \text { - to } \\
\text { cone end }\end{array}$ & $\begin{array}{l}\text { Face1- to } \\
\text { tube end }\end{array}$ & $\begin{array}{l}\text { Face2 - } \\
\text { to cone } \\
\text { end }\end{array}$ \\
\hline G16-P2 -2 & 2.66 & 2.66 & 2.66 & 8.50 & 81.3 & 78.6 & 11.8 & 12.1 \\
\hline G16-P3 -2 & 3.05 & 3.08 & 3.07 & 9.68 & 81.0 & 77.8 & 11.8 & 12.4 \\
\hline G16-P4 -2 & 2.65 & 3.07 & 2.86 & 7.51 & 81.01 & 78.15 & 11.8 & 12.3 \\
\hline G16-P2 -6 & 2.76 & 3.05 & 2.9 & 9.21 & 65.1 & 62.2 & 24.2 & 27.8 \\
\hline G16-P3 -6 & 2.99 & 3.17 & 3.08 & 9.42 & 64.8 & 61.53 & 24.8 & 28.7 \\
\hline G16-P4 -6 & 2.58 & 2.61 & 2.60 & 7.06 & 64.9 & 62.31 & 24.2 & 27.7 \\
\hline G16-P2 -9 & 3.25 & 3.04 & 3.15 & 8.50 & 53.0 & 49.88 & 40.1 & 44.4 \\
\hline G16-P3 -9 & 2.80 & 2.90 & 2.85 & 9.68 & 52.2 & 49.33 & 41.2 & 45.2 \\
\hline G16-P4 -9 & 2.54 & 2.51 & 2.53 & 7.51 & 52.9 & 50.34 & 40.3 & 43.8 \\
\hline
\end{tabular}


To fit the weld coupons to the existing welding apparatus at ORNL, coupon holders were designed and tested. Figure 4 shows the schematic of the welding coupon holder and assembly with the coupons. Three welding coupons were placed between a holder base and a cover plate, and screws were used to fasten the cover plate onto the base of the holder to prevent the movement of coupons. In total, three holder assemblies were used to contain nine weld coupons. Figure 5 shows the actual holder assemblies with coupons. Table 2 lists the coupon IDs and the He concentrations in each holder.

(a) Cover plate
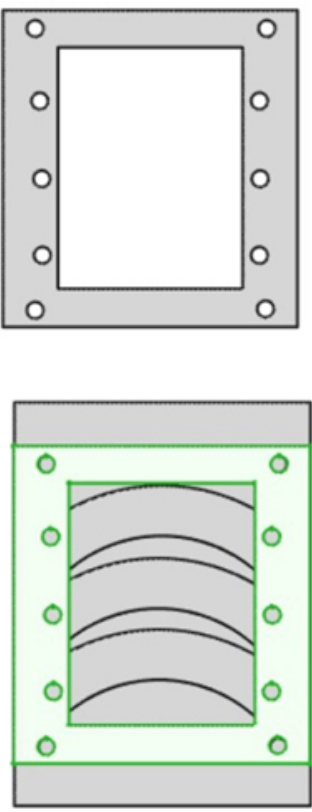

(c) (b) Holder base with coupons
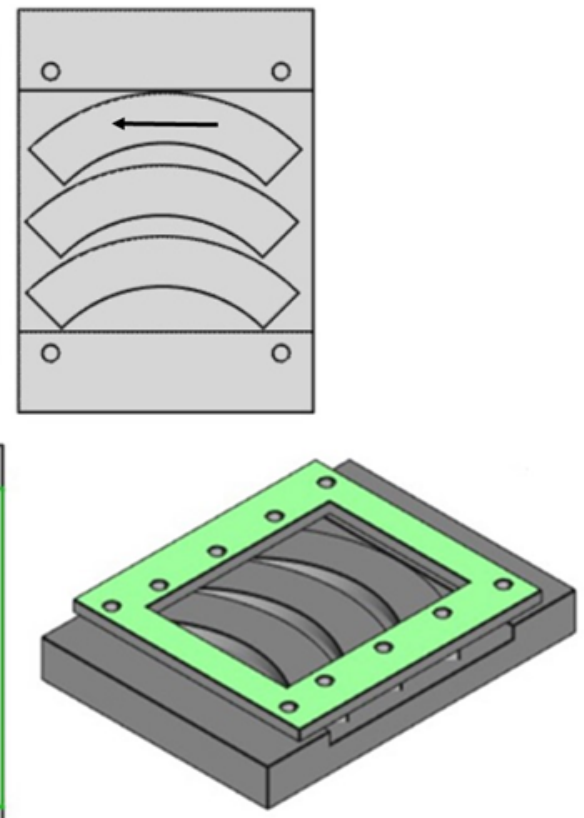

(d) Assembled

Figure 4 Schematic of a coupon holder 


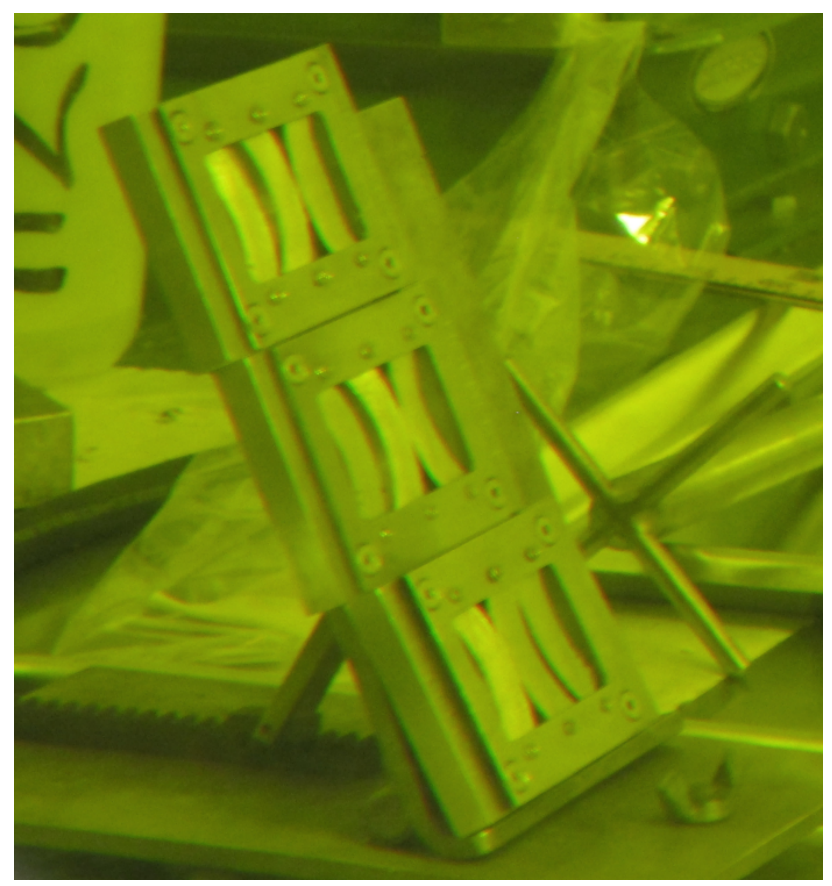

Figure 5 Irradiated SS304 coupons installed in three holders

Table 2 Three coupon holders containing weld coupons with varying He concentrations

\begin{tabular}{|c|c|c|}
\hline & Sample ID & $\begin{array}{c}\text { He concentration at welding } \\
\text { surface (appm) }\end{array}$ \\
\hline \multirow{3}{*}{ Holder 1 } & G16-P2-2 & 12.1 \\
\cline { 2 - 3 } & G16-P3-2 & 12.4 \\
\cline { 2 - 3 } & G16-P4-2 & 12.3 \\
\hline \multirow{4}{*}{ Holder 2 } & G16-P2-6 & 27.8 \\
\cline { 2 - 3 } & G16-P3-6 & 28.7 \\
\cline { 2 - 3 } & G16-P4-6 & 27.7 \\
\hline \multirow{3}{*}{ Holder 3 } & G16-P2-9 & 44.4 \\
\cline { 2 - 3 } & G16-P3-9 & 45.2 \\
\cline { 2 - 3 } & G16-P4-9 & 43.8 \\
\hline
\end{tabular}

\subsection{Selection of welding parameters}

Three welding trials have been performed on unirradiated SS304 to determine the appropriate welding parameters prior to this weld campaign. The list of parameter sets is provided in Table 3. The welding parameters were selected based on the recent successful laser welding of irradiate stainless steels of high levels of helium (Chen, et al, 2021). Additional details of the welding trials on unirradiated SS304 for the welding coupons in this work shown in Figure 4 and Figure 5 of previous section have been reported in the previous report (M2LW-20OR0406015). 
Table 3 Welding parameters in previous trials on CNL's unirradiated SS304

\begin{tabular}{|l|c|c|c|c|c|c|}
\hline Parameter ID & 'L' & 'M' & 'O' & 'P' & 'Q' & 'R' \\
\hline Coupon thickness (mm) & 2.6 & 2.6 & 2.6 & 2.6 & 2.6 & 2.6 \\
\hline Surface conditions & As cut & As cut & As cut & As cut & As cut & As cut \\
\hline Welding laser power (W) & 650 & 800 & 650 & 500 & 650 & 650 \\
\hline ABSI (\% of full output power 2000W) & 0 & 0 & 0 & 0 & 0 & $37 \%$ \\
\hline Wire feed speed (inch/min) & 40 & 40 & 20 & 12 & 15 & 40 \\
\hline Welding travel speed (inch/s) & 0.166 & 0.166 & 0.083 & 0.05 & 0.05 & 0.166 \\
\hline Effective heat input $(\mathrm{KJ} / \mathrm{cm})$ & 0.12 & 0.18 & 0.19 & 0.15 & 0.45 & 0.1 \\
\hline
\end{tabular}

Based on the previous research, there exists a threshold of effective welding heat input as a function of helium concentration for welding of irradiated SS304 (Chen, et al. 2021) as shown in Figure 6 (dashed line). No HeIC forms below the threshold (dashed line), but above the threshold, welds have a high tendency to contain cracks. Selected data on laser beam welding of SS304 including the results obtained in previous weld campaigns (ORNL's boron dopped irradiated SS304 coupons 304B, 304C, 304D and 304E are described in M3LW-20OR0406016). In the current weld campaign for welding CNL's irradiated SS304, three sets of welding parameters (O, P and L as listed in Table 3$)$ with relatively low heat input $(0.12 \sim 0.19 \mathrm{KJ} / \mathrm{cm})$ were selected. Due to the small size of the weld coupons, the auxiliary laser beams to manage weld stresses at high temperatures to minimize cracking could not be used. In addition, our previous results on welding of ORNL's irradiated SS304 suggests that low welding speed allows the weld pool to remain in the molten state for longer times allowing the helium bubbles to escape (M3LW20OR0406016). Thus, parameter sets $M$ and $R$ (with relatively high welding speed) in Table 3 were not used in welding of CNL's SS304 coupons that contains much higher He concentrations. The selection of the welding parameter sets (low heat input and low speed) was to ensure the production of high-quality welds in many of CNL's SS304 coupons. It is noted that a relatively high heat input parameter set Q $(0.45$ $\mathrm{KJ} / \mathrm{cm}$ ) was applied on one coupon that contained the highest He concentration ( $45 \mathrm{appm})$ as shown in Figure 6 . The purpose was to determine whether our current laser welding methodology is capable of producing high-quality welds in high-He-concentration coupons using a high effective heat input without the benefits of ABSI. 


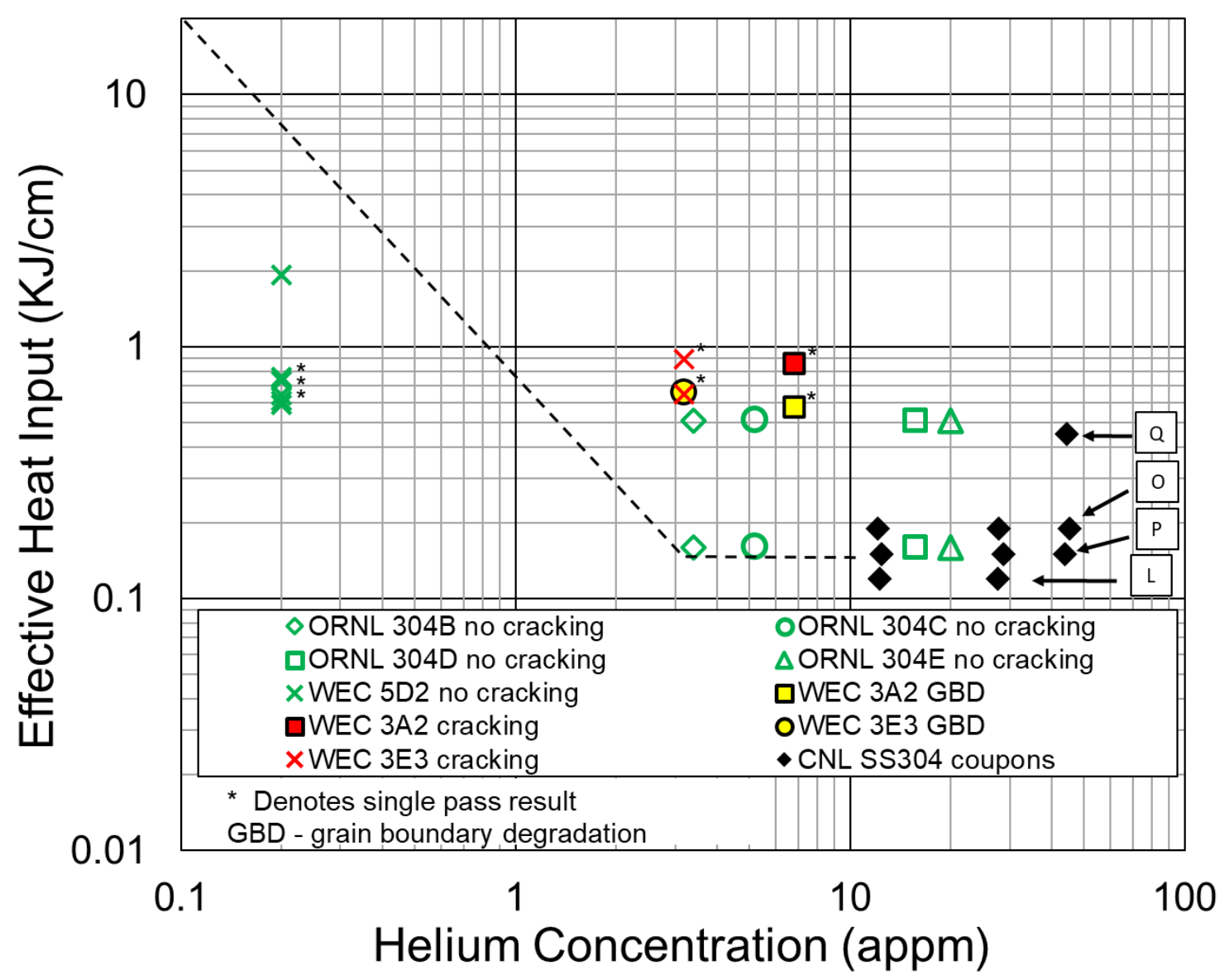

Figure 6 A threshold of effective welding heat input (dashed line) as a function of helium concentration below which no HeIC formed (green symbols). Above the threshold, welds had a high tendency to crack (red symbols). Effective heat inputs used in welding of ORNL's boron dopped SS304 coupons and CNL's SS304 coupons are also indicated in the figure.

\subsection{Welding}

Multi-pass welding was performed on CNL's irradiated SS304 coupons. Since the thickness of the coupons was approximately $2.6 \mathrm{~mm}$, much thinner than ORNL's boron dopped coupons (9mm thick), only one layer of weld metal (308L) was deposited. All weld passes deposited on each individual weld clad were performed using the same welding parameter set. Table 4 lists the details of the sample and welding conditions. It is noted that Sample 2 in Holder 3 (id: G16-P3-9) fell out of the holder during handling before welding due to loose set screws. When the sample was inserted back into the holder, the orientation was unknown. For this reason, it is difficult to distinguish the exact He concentration on the welded surface at this moment. Although it could be either 45.2 or 41.2 appm depending upon the surface on which the welding was performed, it can be determined once CNL disassembles the sample from the holder. For the same reason (loose set screws), Sample 2 in Holder 3 significantly moved creating a large angle during $3^{\text {rd }}$ pass welding. Thus, no additional weld passes were performed on this sample. It is also noted that there was no shielding gas when welding the $1^{\text {st }}$ pass on Sample 3 in Holder 1 (id: G16-P4-2). This could result in a relatively high laser absorption, hence a deeper penetration and a higher tendency of forming porosity and cracks. Figure 7 shows the schematics of the weld passes as well as photos of the 
actual welded coupons with P1 through P6 denoting the sequence of the weld passes. The welding direction is from the top to bottom in this figure. Note that the orientation of Holder 2 was different from the other two holders during welding as shown in the figure.

Table 4 Welding parameters used in the current trial on CNL's irradiated SS304

\begin{tabular}{|c|c|c|c|c|c|c|c|c|c|c|c|c|}
\hline $\begin{array}{c}\text { holder } \\
\#\end{array}$ & $\begin{array}{c}\text { sample } \\
\#\end{array}$ & $\begin{array}{c}\text { sample } \\
\text { ID }\end{array}$ & $\begin{array}{c}\mathrm{He} \\
\text { level } \\
(\mathrm{appm})\end{array}$ & $\begin{array}{l}\text { coupon } \\
\text { thickness } \\
(\mathrm{mm})\end{array}$ & $\begin{array}{l}\text { Weld } \\
\text { pass } \\
\text { length } \\
\text { (inch) }\end{array}$ & $\begin{array}{c}\text { number } \\
\text { of weld } \\
\text { passes }\end{array}$ & $\begin{array}{c}\text { Laser } \\
\text { parameter } \\
\text { set ID }\end{array}$ & $\begin{array}{c}\text { primary } \\
\text { laser power } \\
\text { (W) }\end{array}$ & $\begin{array}{c}\text { travel } \\
\text { speed } \\
\text { (inch/s) }\end{array}$ & $\begin{array}{l}\text { wire feed } \\
\text { speed } \\
\text { (inch } / \mathrm{min} \text { ) }\end{array}$ & $\begin{array}{c}\text { ABSI } \\
\text { power } \\
(\mathrm{kW})\end{array}$ & $\begin{array}{c}\text { Effective } \\
\text { heat input } \\
(\mathrm{kJ} / \mathrm{cm})\end{array}$ \\
\hline \multirow{3}{*}{1} & 1 & $\begin{array}{l}\text { G16- } \\
\text { P2-2 }\end{array}$ & 12.1 & 2.66 & 0.7 & 4 & $\mathrm{O}$ & 650 & 0.083 & 20 & 0 & 0.19 \\
\hline & 2 & $\begin{array}{l}\text { G16- } \\
\text { P3-2 }\end{array}$ & 12.4 & 3.07 & 0.65 & 6 & $\mathrm{P}$ & 500 & 0.05 & 12 & 0 & 0.15 \\
\hline & 3 & $\begin{array}{l}\text { G16- } \\
\text { P4-2 }\end{array}$ & 12.3 & 2.86 & 0.65 & 6 & $\mathrm{~L}$ & 650 & 0.166 & 40 & 0 & 0.12 \\
\hline \multirow{3}{*}{2} & 1 & $\begin{array}{l}\text { G16- } \\
\text { P2-6 }\end{array}$ & 27.8 & 2.9 & 0.65 & 6 & $\mathrm{O}$ & 650 & 0.083 & 20 & 0 & 0.19 \\
\hline & 2 & $\begin{array}{l}\text { G16- } \\
\text { P3-6 }\end{array}$ & 28.7 & 3.08 & 0.65 & 6 & $\mathrm{P}$ & 500 & 0.05 & 12 & 0 & 0.15 \\
\hline & 3 & $\begin{array}{l}\text { G16- } \\
\text { P4-6 }\end{array}$ & 27.7 & 2.6 & 0.65 & 6 & $\mathrm{~L}$ & 650 & 0.166 & 40 & 0 & 0.12 \\
\hline \multirow{3}{*}{3} & 1 & $\begin{array}{l}\text { G16- } \\
\text { P2-9 }\end{array}$ & 44.4 & 3.15 & 0.65 & 5 & Q & 650 & 0.05 & 15 & 0 & 0.45 \\
\hline & 2 & $\begin{array}{l}\text { G16- } \\
\text { P3-9 }\end{array}$ & $\begin{array}{c}45.2 \\
\text { (or } \\
41.2)^{*}\end{array}$ & 2.85 & 0.65 & 3 & $\mathrm{O}$ & 650 & 0.083 & 20 & 0 & 0.19 \\
\hline & 3 & $\begin{array}{l}\text { G16- } \\
\text { P4-9 }\end{array}$ & 43.8 & 2.53 & 0.65 & 6 & $\mathrm{P}$ & 500 & 0.05 & 12 & 0 & 0.15 \\
\hline
\end{tabular}

* The actual He concentration (45.2 versus 41.2 appm) on the welded surface on Sample 2 in Holder 3 is unknown until the sample is disassembled from the holder.
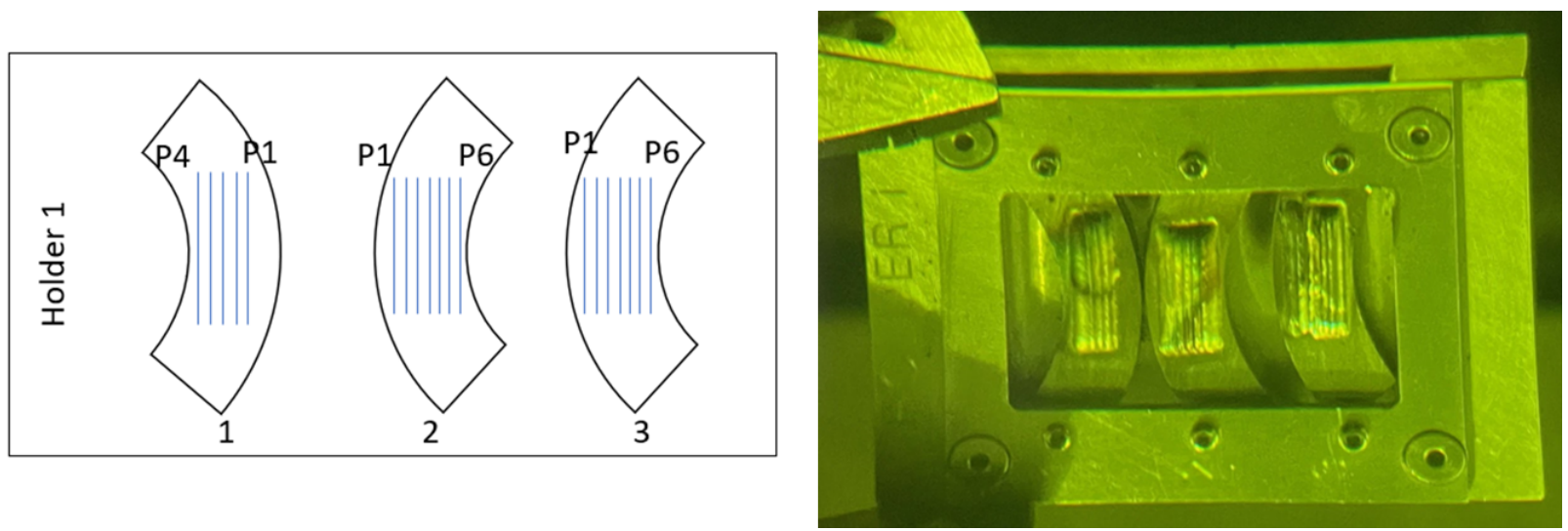

(a) 

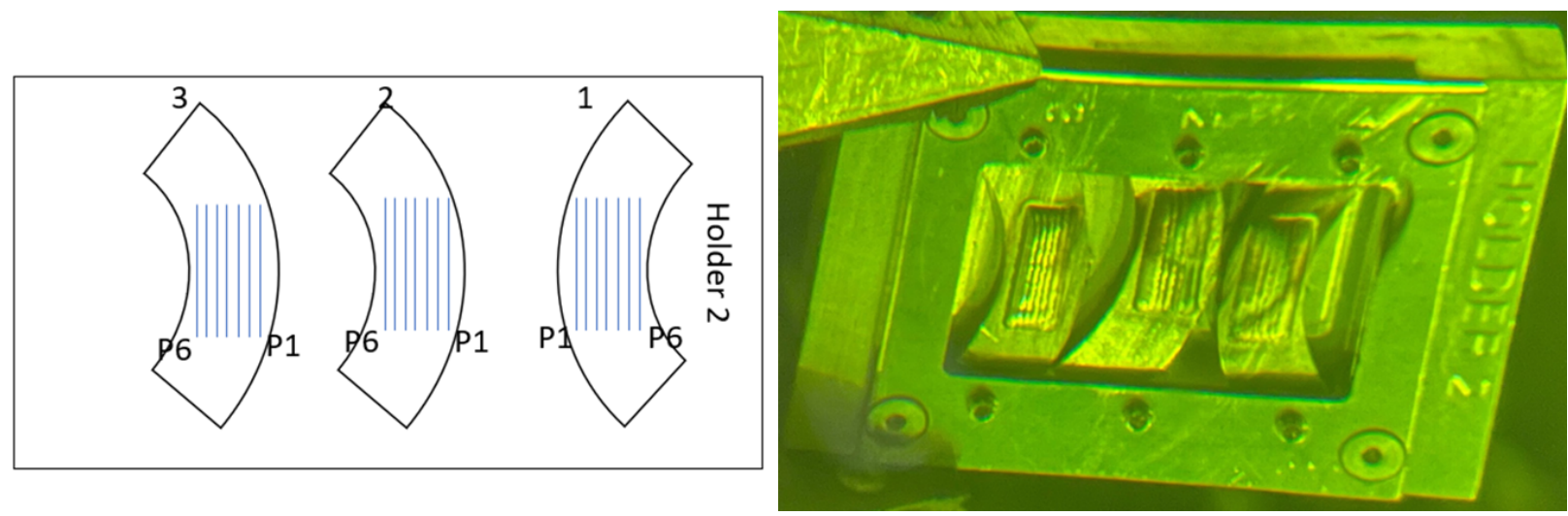

(b)
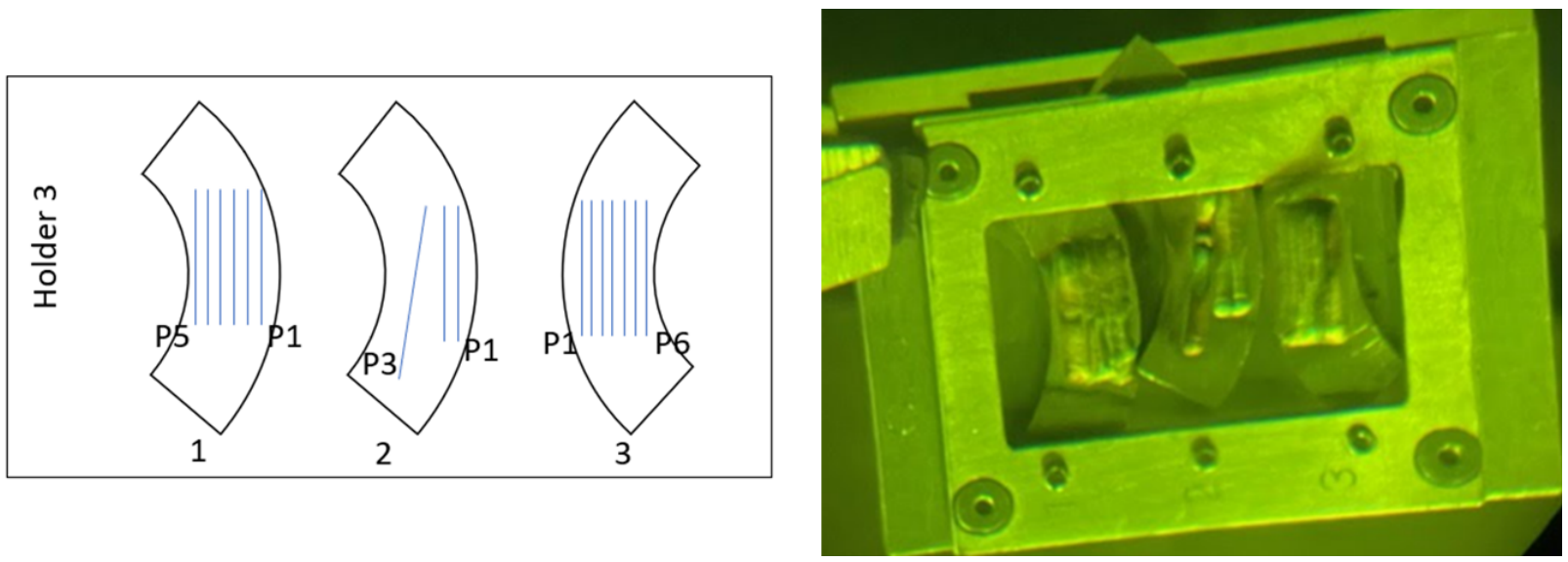

(c)

Figure 7 Schematics of weld passes and photos of the welded CNL's irradiated SS304 coupons in (a) Holder 1, (b) Holder 2 and (c) Holder 3. P1 to P6 denotes the sequence of weld passes.

\subsection{Initial post-weld surface inspection}

The surface quality of the welded coupons was inspected visually using the in-line camera on the laser system as shown in Figure 8. It appears that uniform and smooth weld beads were produced, and no macroscopic cracking (i.e, greater than millimeter size) was observed under visual inspection. More detailed evaluations of the weld quality using optical and electric microscopes will be performed later at CNL based on the Cooperative Research and Development Agreement (CRADA) between ORNL and CNL. 


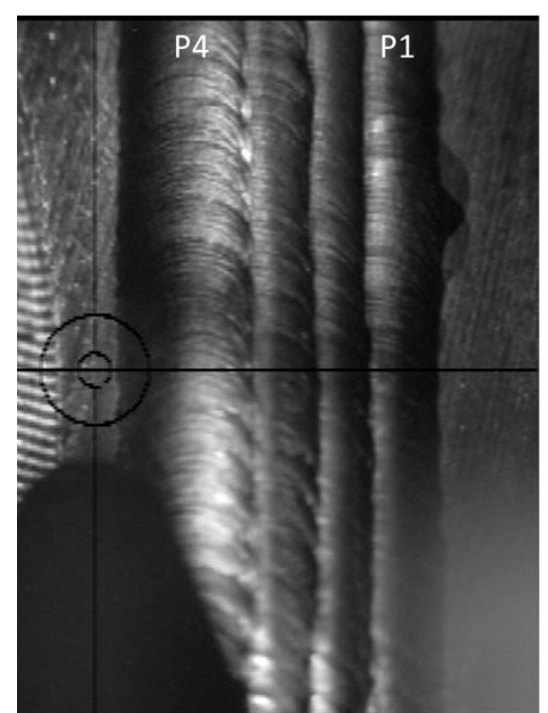

Sample 1 in Holder 1: G16-P2-2

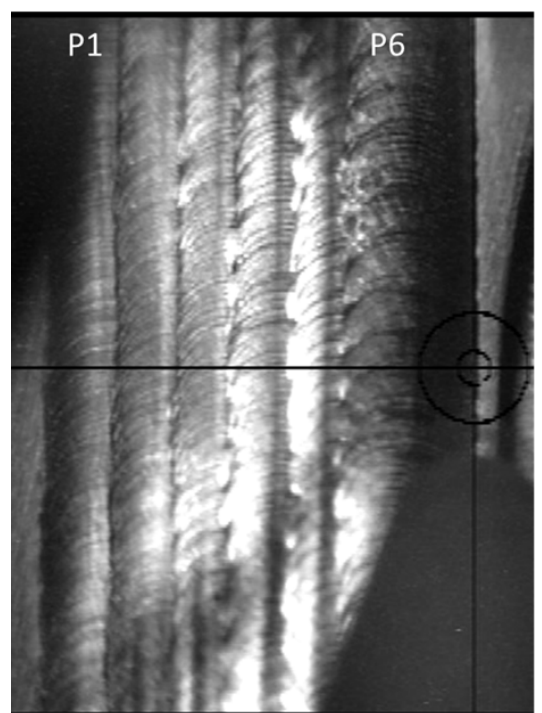

Sample 1 in Holder 2: G16-P2-6

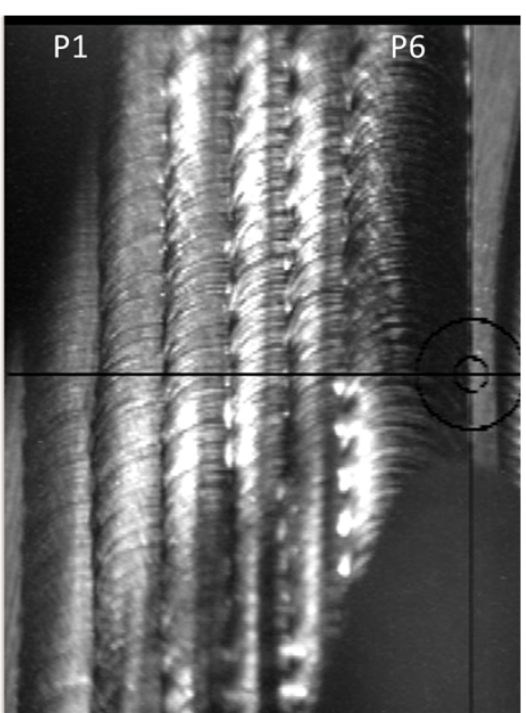

Sample 2 in Holder 1: G16-P3-2

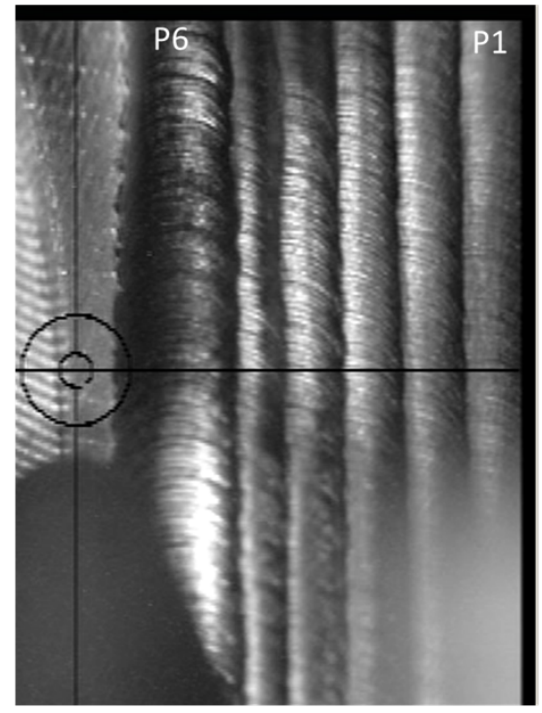

Sample 2 in Holder 2: G16-P3-6

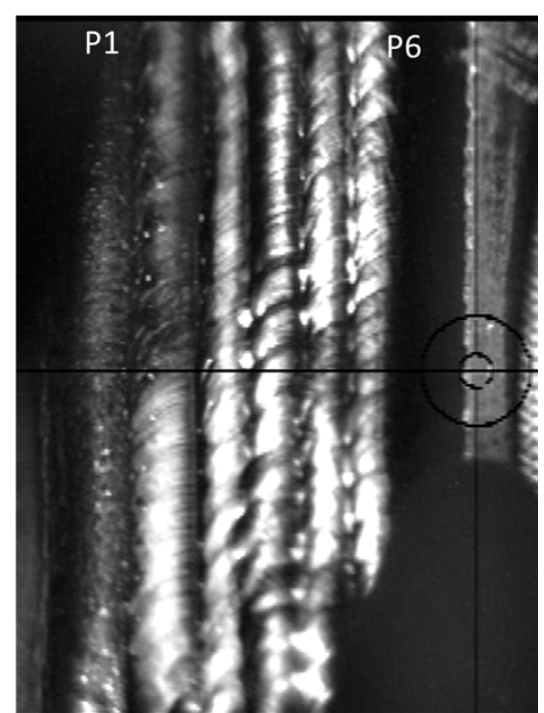

Sample 3 in Holder 1: G16-P4-2

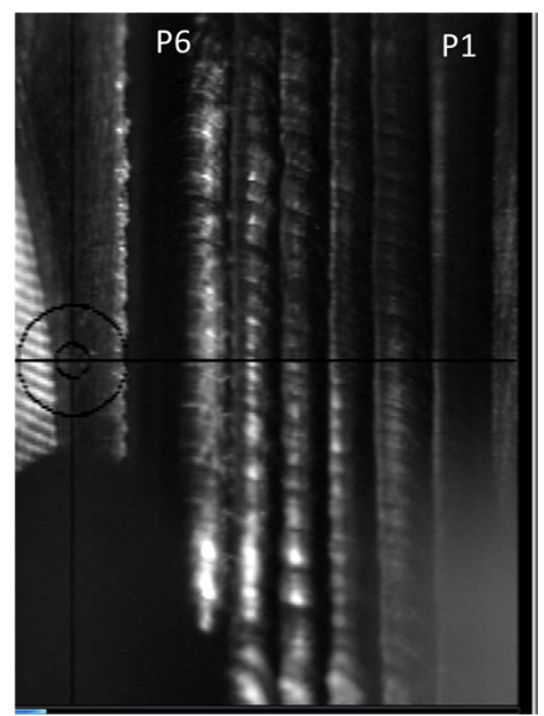

Sample 3 in Holder 2: G16-P4-6 


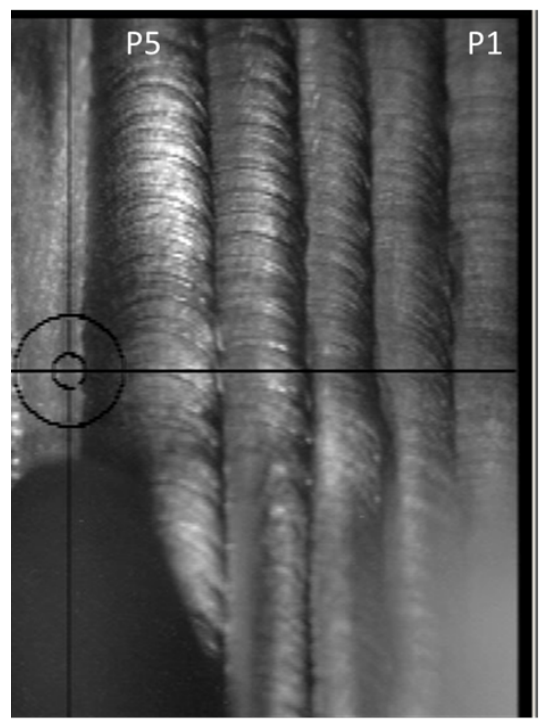

Sample 1 in Holder 3: G16-P2-9

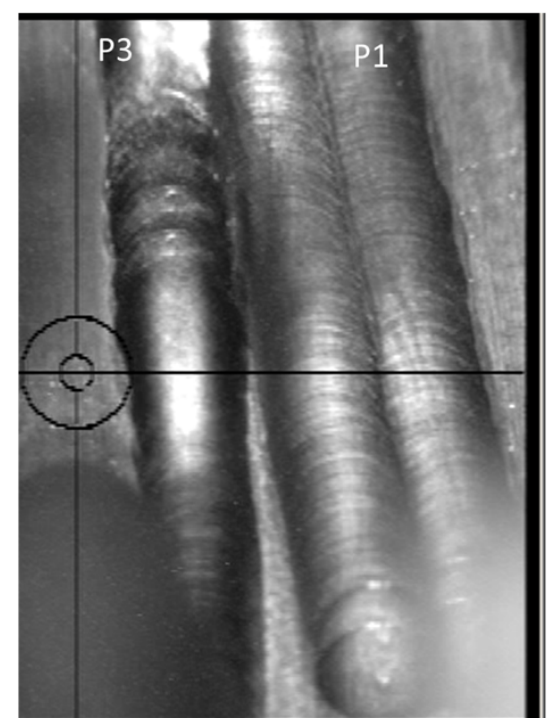

Sample 2 in Holder 3: G16-P3-9

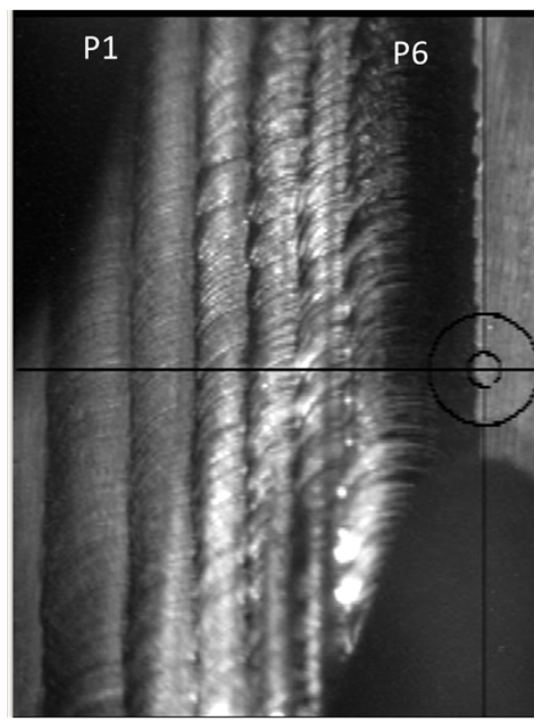

Sample 3 in Holder 3: G16-P4-9

Figure 8 Initial surface inspection of the welded SS304 coupons. P1 to P6 denotes the sequence of weld passes. 


\section{SUMMARY}

This report describes the status of the collaborative research between ORNL and CNL on welding of irradiated materials. ORNL has completed the weld campaigns on 9 irradiated SS304 coupons with high helium concentrations ranging from 12 to $45 \mathrm{appm}$. Significantly, the initial surface inspection using an in-line camera attached to the laser welding head shows no observable cracks. All samples will be shipped back to CNL for further characterizations. 


\section{REFERENCES}

Asano, K., S. Nishimura, Y. Saito, H. Sakamoto, Y. Yamada, T. Kato and T. Hashimoto (1999).

"Weldability of neutron irradiated austenitic stainless steels." Journal of Nuclear Materials 264(1-2): $1-9$.

EPRI (2015). BWRVIP-97, Revision 1: BWR Vessel and Internals Project, Guidelines for Performing Weld Repairs to Irradiated BWR Internals, EPRI.

Feng, Z., R. G. Miller, N. Cetiner, X. Hu, S. Clark, G. Frederick and B. Sutton (2017). Report Summarizing the Status of Second Round Irradiation Experiments and Assessment of Materials Available for Testing Advanced Welding (M3LW-17OR0406013). DOE Light Water Reactor Sustainability Program, Oak Ridge National Laboratory.

Feng, Z., R. G. Miller, J. Chen, M. Gussev, X. Hu, W. Tang, G. Frederick, J. Tatman and B. Sutton (2019). Recent Technological Advances in Welding Irradiated Helium Containing Austenitic Steel (M3LW-19OR0406015). DOE Light Water Reactor Sustainability Program, Oak Ridge National Laboratory.

Feng, Z., R. G. Miller, J. Chen, W. Tang, S. Clark, B. Gibson, M. Vance, G. Frederick, J. Tatman and B. Sutton (2017). Development of Welding Parameters for Irradiated Materials (M2LW17OR0406014). DOE Light Water Reactor Sustainability Program, Oak Ridge National Laboratory.

Feng, Z., W. Tang, R. G. Miller, J. Chen, S. Clark, B. Gibson, G. Frederick, J. Tatman and B. Sutton (2018). Complete Report on Development of Weld Repair Technology (M2LW-18OR0406014). DOE Light Water Reactor Sustainability Program, Oak Ridge National Laboratory.

Feng, Z., W. Tang, R. G. Miller, J. Chen, M. Gussev, S. Clark, G. Frederick, J. Tatman and B. Sutton (2019). Develop Parameters and Characterize the Quality of Friction Stir and Laser Weld-Repaired, Irradiated Structural Materials Representative of Extended Reactor Service Life (M2LW19OR0406014). DOE Light Water Reactor Sustainability Program, Oak Ridge National Laboratory.

Feng, Z. and G. M. Wilkowski (2002). Repair Welding of Irradiated Materials - Modeling of Helium Bubble Distributions for Determining Crack-Free Welding Procedures. 10th International Conference on Nuclear Engineering, ASME.

Feng, Z., K. Wolfe and E. Willis (2009). BWRVIP-228: BWR Vessel and Internals Project: A Computational Modeling Tool for Welding Repair of Irradiated Materials, EPRI.

JNES (2004). FY2003 Nuclear Power Plant Maintenance Improvement Technology (PMT), Japan Nuclear Energy Safety Organization.

JNES (2004). FY2003 Safe Maintenance/Repair Welding Techniques for Nuclear Plant Irradiated Materails (WIM), Japan Nuclear Energy Safety Organization.

Kanne Jr., W. R. (1988). "Remote Reactor Repair, GTA weld cracking caused by entrapped helium." Welding Journal(8): 33-39.

Lin, H. T., M. L. Grossbeck and B. A. Chin (1990). "Cavity Microstructure and Kinetics During Gas Tungsten Arc Welding of Helium-Containing Stainless Steel." Metallurgical Transactions A 21A(9): $2585-2596$.

Willis, E. (2006). BWRVIP-151: BWR Vessle and Internals Project, Technical Basis for Resision to BWRVIP-97 Welding Guidelines, EPRI.

Chen, J., et al. "Suppression of Helium Induced Cracking in Laser Repair Welding of Highly Irradiated Stainless Steels." Journal of Nuclear Materials (2021): 153206.

M3LW-20OR0406016. Chen, J. et al., Complete Key Post-Weld Evaluations and Pre- and PostIrradiation Evaluations of Baseline and Irradiated Weld from FY18 and FY19 Campaigns, September 2020. 